\title{
Community based Financial Practices for Proliferation of Access to Higher Education in Kenya's Asal Regions: A Pointer to Enhancing Peace in the Region
}

\author{
Dr. Clement O. Olando ${ }^{1}$, Muinde Kimuyu ${ }^{2, *}$ \\ ${ }^{1}$ SBE, Mount Kenya University, Kenya \\ ${ }^{2}$ Kensoft Institute of Technology, Kenya
}

Copyright $\bigcirc 2019$ by authors, all rights reserved. Authors agree that this article remains permanently open access under the terms of the Creative Commons Attribution License 4.0 International License

\begin{abstract}
Adequate and quality higher education is important for enhancing peace in most countries as well as among neighbouring communities. However, financial barriers deny Kenyan ASAL communities from accessing higher levels of education, limiting their access to the education necessary for enjoy benefits associated with education such as; employment, adequate incomes and earnings, respectable social status and assured economic security. Limited access to education instead escalates the poverty levels and encourages competition for scarce resources across the vulnerable communities. Prolonged competition for rare resources fuels disputes and conflicts between these communities, threatening peaceful coexistence amongst communities in these area. There is therefore the need for adoption of immediate financial strategies to bridge the gap between basic education and access to higher education for peace to prevail. The present
\end{abstract} study was, as a result, conducted to provide recommendations for ameliorating the persistent conflicts and disputes and consequently provide a platform for peace enhancement in the areas. The study used correlational analysis and purposively sampled 108 parents from Kajiado Central Sub County with children in secondary schools. The data was collected from primary sources using a structured questionnaire and analysed using; quantitative analysis to produce descriptive statistics, correlation analysis and regression analysis for estimating a study model. The study findings reveals that at 5\% (0.05) significance level; each of; diversified sources of funds, resource investment strategy, proficiency of financial knowledge, and financial endowment has positive significant impact on proliferation of access to higher education in Kenya's ASAL regions. The study recommends that the communities in the Kenya's ASAL regions should adopt the community based financial practices through setting common financial pool. The main goals of the pool should investing the funds to generate sufficient income for support school operations and paying for educational services of all the learners fin that community. The community based financial practices should; identify diversified strategies for sourcing funds to support access to education, adopt effective resource investment strategies, employ competent staff to manage their funds, and nurture financial endowment approach. The study suggests that empowering the Kenya's ASAL regions academically would nurture a dependable and sustainable workforce as well as empower the community to create employment, alleviating persistent clashes and eventually enhancing peace.

Keywords Access to Higher Education, Community Based Financial Practices, Diversified Sources of Funds, Peace Enhancement, Proficiency of Financial Knowledge, Resource Investment Strategy, Financial Endowment

\section{Introduction}

The Kenya's education policy, through Education for All (EFA) initiative, has focused on providing equitable, all-inclusive quality education and training for its entire citizenry. ${ }^{1}$ In support of this noble idea, the Government of Kenya (GoK) has emphasised more on expanding learning opportunities to children in the marginalized Arid and Semi-Arid Lands (ASAL) regions. ${ }^{2}$ Unfortunately, these interventions are constraints by shortage of teaching resources such as; inadequate teaching staff, insufficient teaching-learning materials, and more importantly limited financial resources. ${ }^{3}$ Inadequate funding to the Kenyan education sector has denied learning centers in ASAL regions the capacity to engage adequate teaching staff and/or acquire sufficient teaching-learning materials. More precisely, access to higher education in the Kenya's ASAL regions is undermined by lack of adequate financial resource. $^{4}$ Thus, financial resource limitations are 
significantly denying children in the Kenya's ASAL regions access to higher education. ${ }^{5}$ Consequently, children from these regions are vulnerable to adverse effect of lack of sufficient and equitable spread of education such as; unemployment, low income, denial of their social right, and economic insecurity. ${ }^{6}$ This manifests itself in terms of escalating poverty levels in these areas, compelling the communities to compete for rare resources. Prolonged competition for scarce resources is a recipe for disputes and conflicts among the communities sharing land and other resources.

Access to higher levels of education in Kenya has always been associated to the financial capacity of the sponsor (parent or guardian), with lack of adequate financial resource regarded as having the highest limiting factor on access to higher levels of education. ${ }^{5}$ This confirms the position of Brookings Institute $^{7}$ that household income characteristics determine the level of access to basic education and progression to higher levels of education. However, studies have revealed financial resources pooling scheme as an effective practice to sustaining performance. ${ }^{8}$ Meanwhile, common pool theories explain the financial sustainability in terms of financial capital, investment strategy, ${ }^{9}$ financial human capital skills, ${ }^{10,11}$ and material resource capital. ${ }^{12}$

The common pool theory (CPT) proposes that utilisation of common resource attributes ensures yielding favourable results from an investment. ${ }^{13,14}$ In the same line of thought, Oakerson ${ }^{15}$ identifies these attributes as the; physical attributes of utilised specific resource, stewardship capability of stakeholders, the strategies identified, interaction among the stakeholders (decision makers), and yields from the exercises. Based on the suggestion of CPT, this study suggests that physical attributes are related to the financial resources for yielding the sustainable access to higher education in ASAL region. The physical attributes include; the decision-making arrangements to the financial human resource aspect, stakeholders (community), the strategies to the financial practices, and yields (outcomes) for enhancing proliferation of access to higher education.

The Portfolio Theory (PFT) by Markowitz ${ }^{16}$ focuses on maximisation of return in terms of the investment portfolio. In this respect, community members would pool together asset and prudently utilise the most appropriate portfolios for ensuring sustainability. Byers, Groth and Sakao ${ }^{17}$ further postulates that; financial, tangible, and human resources are optimally pooled while focusing on the prospects of sustainability as the expected results. The human resource is important for the daily operations and effectiveness, while the other assets are essential for future uses and for yielding returns. ${ }^{17}$

Accordingly, this study suggested that sustainable access of higher levels of education by ASAL community would therefore be backed by an effective financial resource pooling build upon; diversifying pooled sources of funds, pooled resource investment strategy, financial human capital skills, and financial endowment of material resource capital. The pooled financial resource model therefore takes the form of "gain sharing" and "pain sharing" approach.

\subsection{Problem Statement}

Adequate and quality higher education is important for enhancing peace in most countries and among neighbouring communities. However, financial barriers deny Kenyan ASAL communities from accessing higher levels of education. Children from Kenya's ASAL regions are unable to adequately access higher education due to the lack of adequate financial resources to carter for its provision. ${ }^{18,4}$ Despite Kenya's education system seeking to ensure equity through the EFA initiative, many ASAL regions still lag behind in their quest to access quality higher education, ${ }^{19}$ threatening to dilution of education's levelling effects in the country. ${ }^{20}$ Limited access to higher education by communities in these regions escalates their poverty levels. More so, poverty levels in the affected areas manifest itself as hunger, starvation, poor nutrition, low incomes and, lack of adequate fodder and pasture for livestock on the face of rare resources, which increases competition for scarce natural resources. ${ }^{21}$ Prolonged competition for rare resources fuels disputes and conflicts between the affected communities, rendering peace elusive in these area. ${ }^{22}$ Occasional disputes and conflicts prompt the necessity for enhancing peace through access to adequate and quality higher education in Kenya's ASAL regions. This warrant immediate adoption of financial strategies for bridging the gap between basic education and higher education. Thus financial practices strategies are vital for invariably enhance availability of efficient resources for management of schools and hence provision of adequate access to quality education in ASAL areas. Access to adequate and quality higher education would ensure that communities enjoy; adequate incomes and earnings, respectable social status and assured economic security. This would eradicate poverty as it spells out competition, avoiding disputes and conflicts and eventually enhancing peace in these areas. Despite numerous empirical studies revealing that financial resources determines the level of access to higher education, the relationship between communities based financial practices and access to higher education in ASAL regions in not extensively explored, hence the need for this study.

\subsection{Study Objectives}

The study assessed the impact of a community based financial practices for proliferation of access to higher education in Kenya's ASAL regions as a pointer to enhancing peace in the regions, guided by the specific objectives; 
1. To find out the effects of diversified sources of funds on proliferation of access to higher education in Kenya's ASAL regions.

2. To establish the influence of resource investment strategy on proliferation of access to higher education in Kenya's ASAL regions.

3. To found out the influence of the proficiency of financial knowledge on proliferation of access to higher education in Kenya's ASAL regions.

4. To establish the effects of financial endowment on proliferation of access to higher education in Kenya's ASAL regions.

\subsection{Statistical Hypotheses}

The study tested the null hypotheses;

$\mathrm{H}_{10}$ : Diversified sources of funds does not significantly affect proliferation of access to higher education in ASAL regions of Kenya.

$\mathrm{H}_{20}$ : Resource investment strategy does not significantly influence proliferation of access to higher education in ASAL regions of Kenya.

$\mathrm{H}_{30}$ : Proficiency of financial knowledge does not significantly influence proliferation of access to higher education in ASAL regions of Kenya.

$\mathrm{H}_{40}$ : Financial endowment does not significantly affect proliferation of access to higher education in ASAL regions of Kenya.

\subsection{Justification of the Study}

While $92 \%$ of children in the rich Mount Kenya region have attended secondary schools, only three (3)\% of the poor Northern Kenya regions population have attended secondary schools. ${ }^{23}$ According to statistics, only $0.6 \%$ of Northern Kenya regions population has ever attended any post-secondary school institutions. More so, pupils from Kenya's ASAL regions are unable to access university education as evidenced by $84 \%$ of students admitted to the University of Nairobi coming from high income potential areas and the rest $(16 \%)$ from ASAL areas ${ }^{18}$. These statistics are replicated in the rest of the universities in Kenya, creating a gap between students from rich areas and the poor ASAL regions and also highly threatening to diluting education's levelling effects. ${ }^{20}$ Ultimately, pupils from ASAL regions are denied their rights of access to productive employment, adequate income compelling their communities to retreat into competing for scarce natural resources. Extreme competition for rare resources fuels disputes and conflicts among the community sharing land and other resources. ${ }^{22}$

\section{Literature Review}

\subsection{Theoretical Literature Review}

The study found the Resource Based View Theory (RBV by Penrose ${ }^{24}$ and the Modern Portfolio Theory (MPT) as hypothesised by Markowitz ${ }^{16}$ useful for explain the study concept.

\subsubsection{Resource based View Theory (RBV)}

Penrose $^{24}$ developed the RBV, which proposes that a firm possesses resources that enable it to achieve competitive advantage for a sustained superior long-term organisational performance. Moreover, sustained competitive advantage is created from core resources and competences of the firm. ${ }^{25}$ The theory postulates that the core resources appropriate for improving organisational performance should be; Valuable, Rare, inimitable (VRI), non-substitutable and sustainable over longer. As Barney ${ }^{26}$ puts it, the core resources in the RBV include: routines, culture, invisible assets, human resource, and technology. Meanwhile, Barney ${ }^{25}$ postulates that the commonly cited resources are; finance (capital), human resources (Skills and competencies) and stewardship. ${ }^{26}$ Robert $^{27}$ points out that careful utilisation of these resources requires focusing on the internal environment that ensures sustainability.

Based on these arguments, then this study finds RBV theory very useful in explaining community based financial practices as an effective strategy for extending access to higher education in Kenyan ASAL regions while focusing on the education's internal environment.

The core resource in this respect include; diversified sources of funds, proficiency of financial knowledge (stewardship competency), resource investment strategies, and financial endowment. Therefore, in an effort to increase access to higher education, the affected communities should continuously search for new knowledge which exposes new ways of using these resources as a combined sets of resources. Although schools are essentially non-profit making institutions, they should possess an economic attribute since they need capital while pursuing their core objectives from the required resources. Diversification of the schools' revenue base is essential for sustaining their operations making it therefore emerges prominently ${ }^{25}$.

\subsubsection{Modern Portfolio Theory (MPT)}

The crucial concept in MPT is diversification, where diversification bias is regarded as an enabler to investor (people) in selecting and utilising a wide variety of portfolios. MPT suggests that people considering an investment should employ diversification strategies which spread the contributions evenly across a set of the available investment possibilities. ${ }^{16}$ The theory postulates that competent and proficient financial stewardship, capable of sourcing investments and committed to manage the investments, is essential for the success of a portfolio in having an impact on the investments. Thus, based on the theory, the success of community based financial practices in enhancing proliferation of access to higher education in Kenya's ASAL regions for peace enhancement is propelled 
by capable steward(s) with proficiency in financial matters and capable of diversifying the sourced funds efficiently. The portfolio might be managed by separate team, partnership and whole institution. This study compares separate team to proficiency of financial knowledge, the partnership to community members and parents, and whole institution to all the stakeholders. The theory further suggests that the investors need to emphasis more on portfolio diversification, which points to the diversification of sources of funds.

\subsection{Empirical Literature Review}

In the year 2015 , Mohamed ${ }^{28}$ conducted a study which concludes that School Feeding Program (SFP) significantly improves the pupils' attendance. Another study by Mwavula $^{29}$ revealed that SFP enhanced pupils'; enrolment, attendance, class participation and dropout reduction in Kenya. The study by Yunusa, Gumel, Adegbusi and Adegbus $^{30}$ established that parents are motivated to enroll their children in school and have them regularly attend when there is regular provision of school feeding. Namukwaya and Kibirige ${ }^{31}$ conducted a study which found that harsh environment and chronic food insecurity contributed to withdrawing children from school.

Meanwhile Pansiri and Bulawa ${ }^{32}$ found that parents' support and participation in school related matters significantly sustains children's school attendance. However, Huho and Mugalavai ${ }^{33}$ established that the inability of parents to pay school levies barred children from accessing education. ${ }^{34}$

According to Guthrie, Grittiths and Maron ${ }^{35}$ schools are supposed to generate regular income streams (through either external funding or earned income), adequate enough to cover all operating expense. On the absence of this (adequate income), the future of the school could be on blink of collapse. Reliance on a single area of revenue might ultimately lead to the failure of the school. ${ }^{36}$ Thus, revenue source diversification would promote schools from relying on limited sources of revenue to sufficiency of revenue and subsequently increasing access to adequate and quality education ${ }^{37}$. Olando ${ }^{38}$ established employment of a prudent diversified investment strategy ensures committing funds to planned investment options that have high yields. Notably, investment decisions are profitable when they yield benefits greater than the capital invested. ${ }^{39}$

Although the study by Mwangi and Birundu ${ }^{40}$ concludes that financial resource do not significantly affect the financial performance of a firm, the study by Kinyua ${ }^{41}$ reveals that prudent financing decisions ensures that a firm remains profitable. The study by Mwangi, Makau and Kosimbe $^{42}$ found that adoption of an aggressive financing policy significantly improves the firm performance.

Despite Kweri's ${ }^{43}$ study concludes that investment policy might lead to increasing profitability, the study by Makunyi ${ }^{44}$ showed no relationship between the investment policy and profitability. Abdul and Nasr's ${ }^{45}$ study established that efficient financing of working capital can increase the operating profitability of firms and as such effective policies must be formulated for the individual components of working capital.

A study by Olando, Mbewa and Jagongo ${ }^{46}$ revealed that growth of invested wealth is dependent on competency of financial stewards. Accountability and responsibility to the financial pool members is vitally important for the achievement of sustainability learning institutions. ${ }^{47}$ Policy makers, financial stewards and stakeholders are expected to have an interest in basic understanding of financial matters. There is an increasing need of accountability for both financial and social outcomes. Importantly, the financial staff should be adequately proficient to managing the entire financial management mechanism of the institution. ${ }^{48}$

Mutiso, Onyango and Nyagol ${ }^{12}$ assert that promoting quality education is supported by combinations of endowment funding sources. Endowed funds impact on quality education when the endowment is strategically structured through keeping the principal amount intact while the investment income is available for use. Endowments provide a steady predictable source of income, which schools can make commitments on and build its programs. The financial endowments provide a background income to the school. Baird, McIntosh and Ozler $^{49}$ revealed endowment as an effective approach towards improving schooling enrolment, attendance and academic performance. Hicks et al. ${ }^{50}$ later affirmed that such an approach leads to higher retention rates ${ }^{51}$. According to Sulaiman and Zakari ${ }^{52}$, endowment fund assets play a significantly role in promoting education in rural-urban transformation and can be used to defrayed public expenses in accessing higher education as it also benefits education institutions. Siraj ${ }^{53}$ concludes that endowment mechanism significantly contributes to imparting knowledge and enhancing education, as well uplifting the economic position of deprived communities. ${ }^{54}$

Doloi ${ }^{55}$ had suggested resource pooling as an important and effective approach in developing innovative revenue collection for improving efficiencies within an organisation. Pooled material resource allow schools to realise cost reduction and revenue enhancement.

Basically, learning institutions generate their revenue from; government subsidies ${ }^{56}$, philanthropy donations ${ }^{57}$ and self-generated income ${ }^{36}$. Philanthropy income revenue comes as donations in form of cash, gifts and equipment from individuals, trusts and businesses. The self-generated income is usually fees and levies that are charged for services that has economic activity as well as income from investments ${ }^{36}$.The various sources of funds include; internal financing from the staekoholders ${ }^{58}$, external financing ${ }^{59}$, donations and subsidies $^{60}$, and adequate retained earning capital. ${ }^{61}$ 


\section{Research Methodology}

The study employed the positivist paradigms, since the reality in the present study was that community based financial practices is a factor for enhancing proliferation of access to higher education for enhancing peace in Kenya's ASAL regions. This reality subjected the study to adopting positivist paradigm. Correlational research design was used in assessing the relationship between community based financial practices and proliferation of access to higher education in Kenya's ASAL regions for enhancing peace.

The study targeted the 365 parents from Kajiado Central Sub County (with student in the sub county's public secondary schools) and purposively obtained a sample size of 108 respondents. The study purposively selected only those parents who were well informed on the necessity of financial requirement in the access to higher education. The sample size was $30 \%$ of the target population, which was well above the threshold of $10 \%{ }^{62}$

Data was collected from primary sources using a structured questionnaire and measured on 5 point Likert scale. Although the drop and pick method was used in administration of the research tool, the researcher assisted the respondents in answering questions to make the exercise faster.

Validity test was done using content validity while reliability was tested using internal consistency technique to produce Cronbach's Alpha $(\alpha)$ coefficient as the reliability coefficient. ${ }^{63}$ The reliability test obtained Cronbach's Alpha of .858 as captured in Table 1.

Table 1. Results on Reliability Statistics

\begin{tabular}{lc}
\hline Item & $\begin{array}{c}\text { Cronbach's Alpha } \\
\text { if Item Deleted }\end{array}$ \\
\hline Diversified Sources of Funds & .785 \\
\hline Resource Investment Strategy & .901 \\
\hline Financial knowledge Proficiency & .811 \\
\hline Financial Endowment & .783 \\
\hline $\begin{array}{l}\text { Access to higher learning in Kenya's ASAL } \\
\text { regions }\end{array}$ & .832 \\
\hline Cronbach's Alpha $=0.858, \mathrm{~N}$ of Items $=5$ & \\
\hline
\end{tabular}

Source: Research Data (2018)
The results showed that $\alpha=0.858$, which was well above the 0.7 threshold as recommended by Nunnaly. ${ }^{63}$ This implies a high consistency between the items on the research tool. Since the results indicate that the internal consistency of the questionnaire was high, the study retained all the items in the tool for data collection.

The collected data was analysed using quantitative analysis to produce descriptive statistics and then inferential analysis (correlation analysis and multiple regression analysis) was carried out to produce correlation statistics and regression statistics respectively. As the correlation analysis established existence of relationship between community based financial practices and proliferation and proliferation of access to higher education in Kenya's ASAL regions for enhancing peace, the regression analysis estimated the model explaining proliferation of access to higher education in Kenya's ASAL regions for enhancing peace in terms of; diversified sources of funds, resource investment strategy, financial knowledge proficiency, and financial endowment.

The study used mean of means to convert qualitative data to quantitative data for the study variable. The means (M) were moderated using the statistics; 1 to 1.8 to represent "Not at All"; above 1.8 - 2.6 to represent "Low", above 2.6 to 3.4 to represent "Moderate"; above 3.4-4.2 to represent "High" and above $4.2-5.0$ to represent "Very High".

\section{Results and Findings}

In the section, the study presents the results of; descriptive analysis, correlation analysis and regression analysis.

\subsection{Descriptive Statistics}

The study analysed data using quantitative analysis to produce descriptive statistics. These statistics helped to establish the effects of each of the Independent Variables (IVs); diversified sources of funds, resource investment strategy, and financial endowment, on the Dependent Variable (DV); proliferation of access to higher education in Kenya's ASAL regions. The descriptive statistics are captured in Table 2. 
Table 2. Descriptive Statistics

\begin{tabular}{|c|c|c|}
\hline Indicators of Access to higher learning & $\mathbf{M}$ & SD \\
\hline Improved academic performance & 3.62 & 1.17 \\
\hline Actively participate in learning activities & 3.60 & 1.07 \\
\hline Increased School Attendance (Regularly attend school) & 3.56 & 0.93 \\
\hline Reduce School Drop outs & 3.34 & 0.95 \\
\hline Proliferation of Access to higher learning & 3.53 & 1.03 \\
\hline Indicators of Diversified Sources of Funds & $\mathbf{M}$ & SD \\
\hline Equity (Community/ parents) & 3.68 & 0.75 \\
\hline Retained Earnings & 3.63 & 0.81 \\
\hline Investments (earned income) & 3.56 & 0.73 \\
\hline Government Subsidies & 3.34 & 0.9 \\
\hline Effect of Diversified Sources of Funds & 3.45 & 0.84 \\
\hline Indicators of Resource Investment Strategy & $\mathbf{M}$ & SD \\
\hline Liquid Investments & 3.75 & 0.78 \\
\hline Agricultural/Livestock & 3.46 & 0.88 \\
\hline Transportation & 3.66 & 0.85 \\
\hline Water Resources Development & 3.29 & 0.82 \\
\hline Active participation in school projects & 3.35 & 0.90 \\
\hline Influence of Resource Investment Strategy & 3.5 & $\mathbf{0 . 8 5}$ \\
\hline Indicators of Financial knowledge Proficiency & M & SD \\
\hline Adequate academic qualification (Education) & 3.70 & 0.74 \\
\hline Professional Proficiency & 3.10 & 0.88 \\
\hline Technical Training & 3.17 & 0.97 \\
\hline Group Entrepreneurial activities & 3.80 & 0.74 \\
\hline Influence of Financial knowledge Proficiency & 3.44 & 0.83 \\
\hline Indicators of Financial Endowment & $\mathbf{M}$ & SD \\
\hline Property/Assets & 3.52 & 0.82 \\
\hline Restricted endowments & 3.47 & 0.77 \\
\hline Quasi-endowments & 3.43 & 0.79 \\
\hline Effect of Financial Endowment & 3.47 & 0.79 \\
\hline
\end{tabular}

Source: Research Data (2018

\subsubsection{Proliferation of Access to Higher Education in Kenya's ASAL Regions}

The descriptive analysis began with an assessment on the status of proliferation of access to higher education in Kenya's ASAL regions when using community based financial practices to produce descriptive statistics results in Table 2. These results show that adoption of community based financial practices would highly improve academic performance of the students in Kenyan ASAL regions $(\mathrm{M}=$ 3.62; $\mathrm{SD}=1.17)$. According to these statistics, as utilisation of community based financial practices would ensure that the students actively participate in learning activities $(\mathrm{M}=3.60 ; \mathrm{SD}=1.07)$, it would also lead to increased school attendance $(\mathrm{M}=3.56$; $\mathrm{SD}=0.93)$. However, the application of community based financial practices moderately reduce school drop outs $(\mathrm{M}=3.34$;
$\mathrm{SD}=0.95)$. Based on these statistics, employing community based financial practices would significantly enhance proliferation of access to higher education in Kenya's ASAL regions $(\mathrm{M}=3.53$; $\mathrm{SD}=1.03)$.

\subsubsection{Descriptive Analysis of Study Objectives}

On assessing the study objectives, the results in Table 2 were referenced.

\subsubsection{Effects of Diversified Sources of Funds on Access to Higher Education}

The descriptive statistics of the analysis to find out the effects of diversified sources of funds on enhancing proliferation of access to higher education in Kenya's ASAL regions shows that as equity from the community and parents was found important for enhancing proliferation of access to higher education in Kenya's 
ASAL regions $(\mathrm{M}=3.68 ; \mathrm{SD}=0.75)$, employment of retained earnings as source of financing was also found highly useful for proliferation of access to higher education in Kenya's ASAL regions (mean = 3.63; SD. 0.81). The statistics also show that earned income is essential for enhancing proliferation of access to higher education in Kenya's ASAL regions $(\mathrm{M}=3.56$; $\mathrm{SD}=0.73)$. However, the effect of government subsidies on proliferation of access to higher education in Kenya's ASAL regions was found to be moderate $(\mathrm{M}=3.34$; $\mathrm{SD}=0.90)$. These statistics show diversification of sources of funds in the community based financial practices as highly affecting proliferation of access to higher education in Kenya's ASAL regions $((\mathrm{M}=3.45 ; \mathrm{SD}=0.84)$.

\subsubsection{Influence of Resource Investment Strategy on Access to Higher Education}

The results on assessing the influence of resource investment strategy on enhancing proliferation of access to higher education in Kenya's ASAL regions show that using liquid investments in the community based financial practices would highly contribute to improving proliferation of access to higher education in Kenya's ASAL regions $(\mathrm{M}=3.75 ; \mathrm{SD}=0.78)$. As investing on agricultural and/or livestock products was shown to highly influence proliferation of access to higher education in Kenya's ASAL regions $(\mathrm{M}=3.46 ; \mathrm{SD}=0.88)$, engagement in transportation business was found to highly contribute to proliferation of access to higher education in Kenya's ASAL regions $(\mathrm{M}=3.66$; $\mathrm{SD}=0.85)$. However, investing in water resources development was found to have a moderate effect on proliferation of access to higher education in Kenya's ASAL regions $(\mathrm{M}=3.29 ; \mathrm{SD}=0.82)$ and active participation in school projects was as well found to contribute moderately towards proliferation of access to higher education in Kenya's ASAL regions $(\mathrm{M}=$ 3.35; $\mathrm{SD}=0.90$ ). Resource investment strategy was shown to highly influence the improvement of proliferation of access to higher education in Kenya's ASAL regions $(\mathrm{M}=$ $3.50 ; \mathrm{SD}=0.85$ ).

\subsubsection{Proficiency of Financial Knowledge and Access to Higher Education}

The descriptive statistics on the influence of the proficiency of financial knowledge on enhancing proliferation of access to higher education in Kenya's ASAL regions indicate that adequate academic qualification (education) was necessary for enhancing proliferation of access to higher education in Kenya's ASAL regions $(\mathrm{M}=3.70 ; \mathrm{SD}=0.74)$. Group entrepreneurial activities were found to play a significant role in proliferation of access to higher education in Kenya's ASAL regions $(\mathrm{M}=3.80 ; \mathrm{SD}=0.74)$. However, the professional proficiency in finance $(\mathrm{M}=3.10 ; \mathrm{SD}=$ $0.88)$ and technical training $(\mathrm{M}=3.17 ; \mathrm{SD}=0.97)$ were found to have moderate effect on proliferation of access to higher education in Kenya's ASAL regions. These descriptive statistics show that proficiency of financial knowledge highly influenced proliferation of access to higher education in Kenya's ASAL regions $(M=3.44$; SD $=0.83$ ).

\subsubsection{Effects of Financial Endowment on Proliferation of Access to Higher Education}

On assessing the effects of financial endowment on enhancing proliferation of access to higher education in Kenya's ASAL regions, the study obtained descriptive statistics which show that each of; property and Assets (M $=3.52 ; \mathrm{SD}=0.82)$, restricted endowments $(\mathrm{M}=3.47 ; \mathrm{SD}=$ $0.77)$, and quasi-endowments $(\mathrm{M}=3.43 ; \mathrm{SD}=0.79)$ highly contributed towards proliferation of access to higher education in Kenya's ASAL regions. The effect of financial endowment on proliferation of access to higher education in Kenya's ASAL regions was shown to be high $(\mathrm{M}=3.47 . \mathrm{SD}=0.79)$.

\subsection{Correlation Analysis}

Correlation analysis was carried out to assess existence of relationship between the IVs and the DV and the results obtain captured in Table 3. 
Table 3. Correlations Statistics

\begin{tabular}{|c|c|c|c|c|c|c|}
\hline \multicolumn{7}{|c|}{ Correlations } \\
\hline & & $\begin{array}{l}\text { Access to higher } \\
\text { learning in } \\
\text { Kenya's ASAL } \\
\text { regions }\end{array}$ & $\begin{array}{l}\text { Diversified } \\
\text { Sources of } \\
\text { Funds }\end{array}$ & $\begin{array}{l}\text { Resource } \\
\text { Investment } \\
\text { Strategy }\end{array}$ & $\begin{array}{l}\text { Financial } \\
\text { knowledge } \\
\text { Proficiency }\end{array}$ & $\begin{array}{l}\text { Financial } \\
\text { Endowment }\end{array}$ \\
\hline \multirow{3}{*}{$\begin{array}{l}\text { Access to higher } \\
\text { learning in Kenya's } \\
\text { ASAL regions }\end{array}$} & $\begin{array}{l}\text { Pearson } \\
\text { Correlation }\end{array}$ & 1 & .612 & .589 & .591 & .559 \\
\hline & $\begin{array}{l}\text { Sig. } \\
\text { (2-tailed) }\end{array}$ & & .000 & .000 & .000 & .000 \\
\hline & $\mathrm{N}$ & 101 & 101 & 101 & 101 & 101 \\
\hline \multirow{3}{*}{$\begin{array}{l}\text { Diversified Sources } \\
\text { of Funds }\end{array}$} & $\begin{array}{l}\text { Pearson } \\
\text { Correlation }\end{array}$ & & 1 & .709 & .602 & .516 \\
\hline & $\begin{array}{l}\text { Sig. } \\
\text { (2-tailed) }\end{array}$ & & & .000 & .000 & .000 \\
\hline & $\mathrm{N}$ & & 101 & 101 & 101 & 101 \\
\hline \multirow{3}{*}{$\begin{array}{l}\text { Resource Investment } \\
\text { Strategy }\end{array}$} & $\begin{array}{l}\text { Pearson } \\
\text { Correlation }\end{array}$ & & & 1 & .558 & .473 \\
\hline & $\begin{array}{l}\text { Sig. } \\
\text { (2-tailed) }\end{array}$ & & & & .000 & .000 \\
\hline & $\mathrm{N}$ & & & 101 & 101 & 101 \\
\hline \multirow{3}{*}{$\begin{array}{l}\text { Financial knowledge } \\
\text { Proficiency }\end{array}$} & $\begin{array}{l}\text { Pearson } \\
\text { Correlation }\end{array}$ & & & & 1 & .606 \\
\hline & $\begin{array}{l}\text { Sig. } \\
\text { (2-tailed) }\end{array}$ & & & & & .000 \\
\hline & $\mathrm{N}$ & & & & 101 & 101 \\
\hline \multirow{3}{*}{ Financial Endowment } & $\begin{array}{l}\text { Pearson } \\
\text { Correlation }\end{array}$ & & & & & 1 \\
\hline & $\begin{array}{l}\text { Sig. } \\
\text { (2-tailed) }\end{array}$ & & & & & \\
\hline & $\mathrm{N}$ & & & & & 101 \\
\hline
\end{tabular}

Source: Research Data (2018)

According to these results, probability value (p-value) for each the IV; diversified sources of funds ( $\mathrm{p}$-value $=$ 0.000 ), financial knowledge proficiency ( $p$-value $=0.000$ ), resource investment strategy ( $\mathrm{p}$-value $=0.000)$, and financial endowment ( $p$-value $=0.000$ ) was less than 0.05 , implying each significantly related to access to higher learning in Kenya's ASAL regions. Further, there is evidence of existence of a high significant relationship between each IVs and DV since the correlation coefficient (r) for each comparison (between each IV and the DV), was greater than 0.5. Diversified sources of funds had the highest relationship $(\mathrm{r}=.612)$, followed by financial knowledge proficiency $(\mathrm{r}=0.591)$, then resource investment strategy $(\mathrm{r}=0.589)$, and lastly financial endowment $(\mathrm{r}=0.559)$.

\subsection{Regression Analysis}

On regressing the IVs and DV, using multiple regressions, results Table 4 were obtained. 
Table 4. Regression Statistics

\begin{tabular}{|c|c|c|c|c|c|}
\hline \multicolumn{6}{|c|}{ ANOVA $^{\mathrm{a}}$} \\
\hline & Sum of Squares & df & Mean Square & $\mathrm{F}$ & Sig. \\
\hline Regression & 25.744 & 4 & 6.436 & 24.56 & $0.000^{\mathrm{b}}$ \\
\hline Residual & 25.157 & 96 & 0.262 & & \\
\hline Total & 50.901 & 100 & & & \\
\hline \multicolumn{6}{|c|}{ Coefficients $^{\mathrm{b}}$} \\
\hline & \multicolumn{2}{|c|}{ Unstandardized Coefficients } & Standardized Coefficients & \multirow{2}{*}{$\mathrm{t}$} & \multirow{2}{*}{$\mathrm{p}$-value } \\
\hline & $\mathrm{B}$ & Std. Error & Beta & & \\
\hline (Constant) & -0.017 & 0.367 & & -0.046 & 0.963 \\
\hline Diversified Sources of Funds & 0.245 & 0.120 & 0.226 & 2.053 & 0.043 \\
\hline Resource Investment Strategy & 0.256 & 0.128 & 0.211 & 2.008 & 0.047 \\
\hline Financial knowledge Proficiency & 0.252 & 0.125 & 0.204 & 2.021 & 0.046 \\
\hline Financial Endowment & 0.258 & 0.110 & 0.219 & 2.351 & 0.021 \\
\hline \multicolumn{6}{|l|}{$\mathrm{R}=.711^{\mathrm{b}}$} \\
\hline \multicolumn{6}{|l|}{ R Square $=.506$} \\
\hline \multicolumn{6}{|l|}{ Adjusted R Square $=.485$} \\
\hline \multicolumn{6}{|l|}{ Std. Error of the Estimate $=.51191$} \\
\hline \multicolumn{6}{|c|}{ a. Dependent Variable: Access to higher learning in Kenya's ASAL regions } \\
\hline
\end{tabular}

\section{ANOVA}

Using Analysis of Variance (ANOVA), the study tested the goodness of fit of the regression model. It developed a null hypothesis stating that each of the coefficient of IVs; diversified sources of funds, resource investment strategy, financial knowledge proficiency, and financial endowment respectively is zero (that is $\mathrm{H}_{0}: \beta_{1}=\beta_{2}=\beta_{3}=\beta_{4}=0$ ) and an alternate hypothesis that at least one of these coefficient was not Zero $\left(H_{a}:\right.$ At least one $\left.\beta_{i} \neq 0\right)$. The results $(\mathrm{F}=24.560, \mathrm{P}$-value $=0.000)$ in Table 4 show that $\mathrm{p}$-value $=$ 0.000 which is less that $<0.05$. So $\mathrm{H}_{0}$, is rejected while $H_{\alpha}$ is accepted, implying that at 0.05 level of significance, at least one of; diversified sources of funds, resource investment strategy, financial knowledge proficiency, and financial endowment is useful in predicting proliferation of access to higher learning in Kenya's ASAL regions.

\section{Hypothesis Testing}

Hypothesis 1;

$\mathrm{H}_{0}$ : Diversified sources of funds does not significantly enhance proliferation of access to higher education in ASAL regions of Kenya.

The results $(\mathrm{T}=2.053$, $\mathrm{p}$-value $=0.043)$ indicate that $\mathrm{p}$-value is less than 0.05 , which lead to rejection of $H_{0}$ and acceptance of $H_{0}$. So, at 0.05 level of significance, diversified sources of funds is useful as an estimator of proliferation of access to higher learning in Kenya's ASAL regions.
Hypothesis 2;

$H_{0}$ : Resource investment strategy does not significantly influences proliferation of access to higher education in ASAL regions of Kenya.

The results $(\mathrm{T}=2.008$, $\mathrm{p}$-value $=0.047)$ indicate that the p-value $<0.05$. So, $H_{0}$ is rejected and $H_{\alpha}$ accepted, implying that at 0.05 level of significance, resource investment strategy is not zero and is therefore it is a useful predictor of proliferation of access to higher learning in Kenya's ASAL regions.

Hypothesis 3;

$H_{0}$ : Proficiency of financial knowledge does not significantly influence proliferation of access to higher education in ASAL regions of Kenya.

In the results $(\mathrm{T}=2.021, \mathrm{p}$-value $=0.046)$, the $\mathrm{p}$-value is less than 0.05 . So, $H_{0}$ is rejected and $H_{\alpha}$ accepted, indicating that at 0.05 level of significance, there exists enough evidence to conclude that the proficiency of financial knowledge is not zero and, hence it a useful predictor of access to higher learning in Kenya's ASAL regions.

\section{Hypothesis 4;}

$H_{0}$ : Financial endowment does not significantly influence proliferation of access to higher education in ASAL regions of Kenya

The results $(\mathrm{T}=2.351, \mathrm{p}$-value $=.021)$ show that $\mathrm{p}$-value $<0.05$. Therefore, $H_{0}$ is rejected and $H_{\alpha}$ accepted, an implication that at 0.05 level of significance, there exists 
enough evidence to conclude that the financial endowment is not zero and, hence, it is useful as a predictor of access to higher learning in Kenya's ASAL regions.

So, diversified sources of funds, resource investment strategy, financial knowledge proficiency, and financial endowment are predictors of in proliferation of access to higher learning in Kenya's ASAL regions.

\section{Predicted Model}

Using the results in Table 4, the predicted model is $\mathrm{Y}=-0.017+0.254 \mathrm{X}_{1}+0.256 \mathrm{X}_{2}+0.252 \mathrm{X}_{3}+0.258 \mathrm{X}_{4}$.

This means that the predicted proliferation of access to higher learning in Kenya's ASAL regions for peace enhancement is $(\mathrm{Y})=-0.017$ (cons) +0.254 diversified sources of funds $\left(\mathrm{X}_{1}\right)+0.256$ resource investment strategy $\left(\mathrm{X}_{2}\right)+0.252$ financial knowledge proficiency $\left(\mathrm{X}_{3}\right)+0.258$ financial endowment $\left(\mathrm{X}_{4}\right)$. Thus, the proliferation of access to higher learning in Kenya's ASAL regions decreases by 0.017 units regardless of whether the explanatory variables for community based financial practices are present or not. One unit change in diversified sources of funds leads to a 0.254 unit increase in the proliferation of access to higher learning in Kenya's ASAL regions and vice versa while one unit change in resource investment strategy leads to a 0.256 unit increase in the proliferation of access to higher learning in Kenya's ASAL regions and vice versa. As a one unit increase in financial knowledge proficiency leads to a 0.252 unit increase in proliferation of access to higher learning in Kenya's ASAL regions and vice versa, a one unit change in financial endowment leads to a 0.258 unit increase in proliferation of access to higher learning in Kenya's ASAL regions and vice versa. The results show that $48.50 \%$ of variation in proliferation of access to higher learning in Kenya's ASAL regions is explained by diversified sources of funds, resource investment strategy, financial knowledge proficiency, and financial endowment.

Notably, each of the predictors; diversified sources of funds, resource investment strategy, financial knowledge proficiency, and financial endowment, has a positive significant effect the response; on proliferation of access to higher learning in Kenya's ASAL regions.

\subsection{Conclusions}

The study concludes that community based financial practices has a positive significant effect on proliferation of access to higher learning in Kenya's ASAL regions. The adoption of community based financial practices contributes significantly towards improvement of proliferation of access to higher learning in Kenya's ASAL regions. This is informed by the recommendation in the study by Pansiri and Bulawa ${ }^{32}$ that stakeholders' support on school related matters assists in sustaining children's school attendance. Provision of adequate resources required by the students, motivates them to attend school regularly and allows for their active participation in learning activities. ${ }^{29}$ Huho and Mugalavai ${ }^{33}$ revealed that the inability of parents to provide financial resources makes it difficult for children to access education. ${ }^{34} \mathrm{The}$ community based financial practices strategy would ensure that every stakeholders contributes equitably towards education of the community's children. An effectively managed community based financial practices provides a platform for improving academic performance of children in schools. ${ }^{28-30}$ As revealed that by Huho and Mugalavai ${ }^{33}$, implementation of community based financial practices would ensure raising sufficient funds for supporting school operations and opens a window for all the children in Kenya's ASAL regions to assess higher education. Further, access to quality and adequate higher education, by the deserving children from Kenya's ASAL regions, creates an opportunity for these children to gain the benefits associated with higher education cutting across; assured employment, adequate incomes and earnings, respectable social status and assured economic security. Notably, economic security is the pathway to provision of basic needs. This marks journey to liberation of communities from occasionally competing for rare natural resources such as land, water and pastures. Absence of such competition completely erases occurrence of conflict and disputes, promoting peace enhancement in the Kenya's ASAL regions. ${ }^{6}$ Once the communities in the Kenya's ASAL regions are economically secure, they would stop fighting for scarce resources, promoting peace enhancement in these areas. Thus, peace is child of adoption of the community based financial practices. The study reveals that $48.50 \%$ of variation in proliferation of access to higher learning in Kenya's ASAL regions is explained by diversified sources of funds, resource investment strategy, financial knowledge proficiency, and financial endowment.

The study concludes that diversified sources of funds in the community based financial practices strategy has a positive significant effect on proliferation of access to higher learning in Kenya's ASAL regions. The key sources of financing the community based financial practices are; equity for community and parents, retained earnings, investments (earned income), government subsidies and school fees. When fund raised by community and parents (equity) are pooled and invested in profitable ventures, they generate profits adequate to supporting school programs as well for financing education for the needy children amongst them. Surplus (retained earnings) reserved from the profit gained from investments in the profitable projects, may also be ploughed back for reinvestment. The stakeholders are encouraged to set up project outside the school program (earned income) and the proceeds from the projects used for investment in school community based financing. Importantly, the investment 
yield high returns and significant profits. Sufficiency of profit implies adequacy of funds for financing education in these areas, an assurance of access to adequate and quality higher education in Kenya's ASAL regions. As Mwangi et $a l .{ }^{42}$ revealed, adoption of an aggressive financing policy, through diversification sources of funds, would yield tangible income to the school for supporting access to higher education in Kenya's ASAL regions. Meanwhile, Kinyua's ${ }^{41}$ study concludes that prudent financing decisions ensure that a firm remains profitable. In the present study, diversifying the sources of funds significantly increase the profitability of schools hence sustainability of access to higher education since it has a positive significant influence on proliferation of access to higher education in Kenya's ASAL regions.

The study concludes that resource investment strategies in community based financing strategy have a positive significant influence on proliferation of access to higher education in Kenya's ASAL regions. The main resource investment strategies essential for proliferation of access to higher education in Kenya's ASAL regions are; investing in liquid investments, engaging in transportation service for profits, investing on agricultural and/or livestock products, active participation of the community and parents, and investing on water resources development, in that order. This is built on the findings in the study by Kweri ${ }^{43}$, which concludes that adopting the most appropriate resource investment policy leads to increased profitability. ${ }^{44,45}$ Effective resource investment policies must be formulated for the individual components of community financing program and should focus on optimising its profits. The higher profitability and the availability of adequate financial resource to support the school operations and expenditures, the higher the opportunities to access to higher education in Kenya's ASAL regions. Kinyua ${ }^{41}$ proposes for application of the pecking order theory and information asymmetrical theory to importantly increase the profitability.

The study concludes that proficiency of financial knowledge in the community based financial practices strategy has positive significant influence on proliferation of access to higher education in Kenya's ASAL regions. The study revealed the key requirements for proficiency of financial knowledge as; adequate academic qualification (education), professional proficiency in finance, sufficient technical training, and formation of group entrepreneurial activities for the communities. In the community based financial practices strategy, effective management of the pooled financial resource is enhanced by financial steward, possessing adequate academic qualification (education) and proficiency in finance. This is based on the premise that financial stewardship competency influence the growth of invested wealth. ${ }^{46}$ Accordingly, these financial stewards are required to have sufficient relevant training in financial matters for making appropriate financing decisions. Proper financing decisions identify that best projects to yield optimum profit and for achievement of the core objective. The community stakeholders are also required to attain substantial entrepreneurial skills and financial knowledge to considerably drive the core objective of the community based financial practices program. Initiating group entrepreneurial activities in the communities creates flow of money within the community and hence availability of education funding. Thus, proficiency of financial knowledge leads to achievement of the core objective; sufficient income to support access to higher education, hence on proliferation of access to higher education in Kenya's ASAL regions.

Finally, the study concludes that financial endowment has a significant positive influence on the proliferation of access to higher education in Kenyan ASAL regions as informed by the findings in the study by Sulaiman and Zakari $^{52}$ that endowment fund assets are vital for the provision of social and economic safety valves through promotion of education. Sulaiman and Zakari ${ }^{52}$ revealed that financial endowment may be used to defray public expenses when accessing higher education and eventually benefiting education institutions. The study by Siraj ${ }^{53}$ contents that endowment mechanism significantly contributes in imparting knowledge and enhancing education among communities. ${ }^{54}$ Based on by the findings in the studies by Sulaiman and Zakari ${ }^{52}$ and Siraj ${ }^{53}$, utilisation of financial endowment would enhance proliferation of access to higher education in Kenya's ASAL regions as it builds economic security to the communities. Some forms of financial endowment include; the community give part of their properties and assets (such as parcels of lands) for use in the community based financial practices, communities participating in restricted endowments, and quasi-endowments.

\section{Recommendations}

\subsection{Policy Recommendations}

The study recommends that the Kenya's ASAL regions should adopt the community financial practises strategy, through formation of registered community groups, for sustenance of education for all their children. Formal registered group for contributing towards the community financial practises strategy should be firmed with Sub wards of counties in Kenya's ASAL regions. These groups should be spearheaded by committees chosen by group members. It is advisable that each families in that sub ward must a member of the group, with the unit of membership being a family. This may be made possible by enactment of community financial practises strategy legal framework by County governments of the Kenya's ASAL regions. Although the group may outsource technical advice from other entities, the executive committee members must be from within the sub ward. The work of the committee is 
making decision making and implementation of the community financial practises strategy requirements. The group is need for overseeing the pooling together of their financials resources and investing these resources for considerable profitable gain. Part of the proceeds (profits) from the investments should be used to support the school operations and the surplus from the profits generated (retained Earnings) ploughed back for reinvestment as part of capital structure. The profits should be sufficient to support the education requirements of the children deserving higher education in that area. The community may obtain funding for the common pool from individual member's contributions (equity raised form contributions by the community member, parents with children in the learning institutions, guardians, and well-wishers). Other source of funds might include; donations, school fees raised by the parents, bursaries and government subsidies.

The pooled system should importantly diversify its capital structure (source of funds) and as well identify the most appropriate source of funds for optimum wealth generation. The study recommends that pooled scheme should invest the financial resource wisely for the purpose of maximising profits. The profits from the investments should be sufficient for supporting all the schools' operations and reserving substantial earning surpluses (for the purpose ploughing into the capital base as retained earnings and for cushioning operational losses). The pooled scheme requires prudent allocation of its funds for optimal financial gain (profits), using the most appropriate investment strategy The study recommends that the funds' investment strategy for community based financial practices scheme should; use liquid investments, invest on agricultural and livestock products, engage in transportation business, and initiate water resources development project public use and for a charge.

The study recommends that the operational staff (financial stewards) of the community financial practises should be proficient and competent in finance matters; possessing high academic qualifications and vast experience in finance. The financial stewards should be highly informed on financial matters for; making valuable financial decisions on capital structure, investment portfolio, and funds allocation strategy. They should possess adequate qualifications for making productive financial decisions. The community members should be encouraged to form group entrepreneurial activities such; as table banking, Rotating Savings and Credit Associations (ROSCA), and Accumulating Savings and Credit Associations (ASCAs). This would expose the community to financial spheres, bringing light into the event and activities taking place within the pooled scheme and thus allaying fears.

Lastly the study recommends that the community should encourage financial endowment by donating property and assets to the learning institutions for use towards the investment. Some of the proceeds from the investment should be used for school operations and the rest paid to the property owners as compensation for property use. The schools might also use the land for production of some schools' essential commodities such as food, milk and water. Restricted endowments such as endowment revenue, endowed professorships or endowed scholarships, may be provided by interested parties to fund specific areas within the schools. Endowment revenue may be restricted by donors to serve many purposes. In endowed professorships or scholarships, the donor would fund a trust exclusively for the support of an activity in the school. An endowed professorship is where the donor would be financially supporting certain teachers within the schools while the endowed scholarship, which merit-based or need-based, is where tuition assistance and possibly other cost that are paid by donors, especially for children from family with financial constraints. The community may also provide for quasi-endowment (fund functioning), where funds are merely earmarked to be invested to provide income for a long period.

The implementation of the community based financial practices would enhance proliferation of access to higher education in Kenya's ASAL regions. The children having access to higher education would enjoy the immense benefits in terms of employment, higher economic income, acquisition of social status, and assured economic security. The communities would therefore enjoy high level of poverty reduction as they reap high income. Consequently, the communities will cease from fighting for rare resources to a self-sustained people, creating the most desired opportunity of assured peace enhancement. The adoption of the community based financial practices would enhance proliferation of access to higher education in Kenya's ASAL regions, resulting into increased incomes and abundance of resources and hence enhancement of peace in Kenya's ASAL regions.

\subsection{Limitations of the Study}

The study embarked on collecting data from Kajiado Central Sub County, which limited the applicability of the results to Kajiado County. It was established that Kajiado Central Sub County is regarded as one of the county having serious challenges in access higher education due to the lack of adequate financial resources to carter for the provision and hence conflicts within the communities sharing resources. So, other studies should be conducted to assess the community based financial practices for proliferation of access to higher education for enhancing peace in Kenya's ASAL regions regarded as facing similar challenges.

The study found that $48.50 \%$ change of proliferation of access to higher education for enhancing peace in Kenya's ASAL regions is explained diversified sources of funds, financial knowledge proficiency, resource investment strategy, and financial endowment. This means that there 
are other factors that account for the remaining $51.50 \%$. So other studies should be conducted to establish the factors influencing the $51.50 \%$ change of proliferation of access to higher education for enhancing peace in Kenya's ASAL regions.

The study established that liquid investments is a factor of resource investment strategies essential for proliferation of access to higher education in Kenya's ASAL regions. However, there were no specificity on the particular liquid investments

\subsection{Policy Implication}

The study findings and recommendations have important policy implications to the policy makers in the Kenyan education sector when formulating policies on access to quality education in the ASAL region. Importantly, ASAL region communities will acquire a supportive environment for their children to access education equitably as any other children in the Republic of Kenya $^{64}$ and remain in school ${ }^{65}$ despite the challenges and difficulties posed by drought. These ASAL communities will gain immense benefits in terms of employment, higher economic income, acquisition of social status and assured economic security. Thus, it will ensure empowering the local communities to come out of the cycle of poverty, improving economic growth and increasing their productivity in the long run as it enhances peace in these volatile regions

\subsection{Contribution to Knowledge}

The study will add knowledge to financial management field, useful to academicians and scholars. The study will be a window opener on the areas of community based financial practices for financial sustainability of schools, making it a base for further research on the area of community based financial practices for proliferation of access to higher education in Kenya and enhancing peace in ASAL regions.

\section{REFERENCES}

[1] Republic of Kenya/UNICEF. Education for All (EFA) end of decade assessment (2001-2010). Nairobi: Ministry of Education and INICEF; 2012

[2] Ministry of Education [MoE]. Various reports on monitoring of mobile schools in Fafi, Lagdera, Wajir West, Wajir East, Ijara, Tana River, Tana Delta, Turkana North and Samburu East Districts. Nairobi: Government Printers; 2009.

[3] Abagi O, Oanda I. Fifty years of educational development in Kenya: Mapping out gains, challenges and prospects for the future (Eds.). Nairobi: Jomo Kenyetta Foundation; 2014.

[4] Orodho JA. (2013). Progress towards attainment of education for all (EFA) among nomadic pastoralists: Do home-based variables make a difference in Kenya. Research on Hum Soc Sci [Internet]. 2013; 54-67. Available from www.iiste.org.

[5] Oketch M, Ngware MW. (eds.). Urbanization and education in East Africa: African population and health research Center; 2012.

[6] Munda SW, Odebero S. The Influence of education costs on students' academic performance in Kenya: An empirical study of Bungoma County Secondary Schools. Asian J Ed Research. 2014; 2(10): 1- 11.

[7] Brookings Institutions. Towards universal learning: What every child should learn. Harvard Ed Rev. 2013; 31:1961.

[8] Pindyck RS, Rubinfeld DL. Microeconomics. 5th ed. Upper Saddle River, NJ : Pearson Prentice Hall; 2005,

[9] Maritala, A.T., (2012). An Empirical analysis of capital structure on firm performance in Nigeria. Int $\mathrm{J} \mathrm{Adv} \mathrm{Mgt}$ Econ. 2012.

[10] Ngicuru PN, Muiru M, Riungo, MI. An empirical review of factors affecting revenue collection in Nairobi county, Kenya. Int J Econ Comm Mgt. 2017; V(8): 324-359.

[11] Otieno PS, Nyikal RA, Mugivane FI. Non-credit services of group-based financial institutions: Implications for smallholder women's money income in arid and semi-arid lands of Kenya. Afri J Agri Res [Internet]. 2010; 5(5), Available from http://www.academicjournals.org/AJAR

[12] Mutiso, Onyango and Nyagol (2015)

[13] Ostrom E. Governing the Commons: The Evolution of institutions for collective action. Cambridge, UK: Cambridge University Press; 1990.

[14] Ostrom, ER, Gardner, Walker JM. Rules, games, and common-pool resources. Michigan: University of Michigan Press; 1994.

[15] Oakerson R. Analyzing the commons: A framework. Workshop in political theory and policy analysis, Bloomington, Indiana: Indiana University; 1990

[16] Markowitz HM. (1952). Portfolio Selection. J Fin. 1952; 7(1):77-91.

[17] Byers SS, Groth JC \& Sakao T. Using portfolio theory to improve resource efficiency of invested capital [Internet]. Linkoping, Sweden: Linkoping University Electronic Press, 2012. Available from http://urn.kb.se/resolve?urn=urn:nbn: se:liu:diva-84858.

[18] Andrew SL, Orodho JA. Socio-Economic factors influencing pupils' access to education in informal settlements: A Case of Kibera, Nairobi County, Kenya. Int J Ed Res. 2014; 2(3): 1-16.

[19] Tavernise S. Education gap grows between rich and poor, studies say. New York Times; 2012.

[20] Limo E. Sex and gender [Internet;]; 2012. Available from http://thecollaboratory.wikidot.com/thompson-social-inequ ality.

[21] The Centre for Science and Technology Innovation Increasing community resilience to drought in Makueni 
District: The Sakai community's experience, Kenya. Nairobi: Centre for Science and Technology Innovation; 2009.

[22] Osman-Elasha B. Managing Africa's water in a changing climate in adapting to climate change in Africa, Joto Afrika [Internet]. 2(2009); 1-7.

[23] Kenya National Bureau of Statistics [KNBS]. Well-Being in Kenya. A socio-economic profile. Nairobi: Government Printers; 2008.

[24] Penrose E. The theory of the growth of the firm. Oxford: Oxford University Press, 1995.

[25] Barney JB. Firm resources and sustained competitive advantage. J Mgt. 1991; 17(1): 99-120.

[26] Barney JB. Looking inside for competitive advantage. Aca Mgt Exe. 1995; 9(4): 49-65.

[27] Grant, R. The resource based theory of competitive advantage: Implication of strategy formulation. Calif Mgt Rev. 1991; 33(3).

[28] Mohamed, A. O. (2015). Influence of feeding programs on the participation of learners at early childhood development education institutions: A case of Bungoma South district. International Aca J Soc Sci Ed. 2015; 1 (4), 1-14.

[29] Mwavula, MA. Influence of school feeding programme on pupils' participation in public primary schools in flood prone areas of Garsen Division, Tana Delta District, Kenya [Unpublished Master's research project]. Nairobi, Kenya: University of Nairobi; 2014.

[30] Yunusa I, Gumel A, Adegbusi K, Adegbusi S. School feeding program in Nigeria: A vehicle for nourishment of pupils. The Afri Symp. 2012; 12(2): 104-110.

[31] Namukwaya VA, Kibirige I. (2014).Factors affecting primary school enrolment and retention of pupils in Kotido District, Uganda. Med J Soc Sci. 2014; 5(8): 423-430.

[32] Pansiri NO, Bulawa P. Parents' participation in public primary schools in Botswana: Perceptions and experiences of head teachers. Int Edu Stud. 2013; 6(5): 68-77.

[33] Huho JM, Mugalavai EM. The Effects of droughts on food security in Kenya. The Int J Clim Chng: Imp Resp. 2010; 2(2): 61-72.

[34] Salee M. D. Influence of school feeding program on pupils' participation in public primary schools in Masinga division in Machakos County [Unpublished Master's project]. Nairobi, Kenya: University of Nairobi, 2013

[35] Guthrie K., Grittiths, R, Maron N. (2008). Sustainability and revenue models for online academic resources [Internet]. Available

from http://www.jisc.ac.uk/media/documents/themes/eresources/ sca_ithaka_sustainability_report-final.pdf

[36] Carroll DA, Stater KJ. (2008). Revenue diversification in non-profit organizations: Does it lead to financial stability? J Pub Adm Res Theory [Serial Online]. 2008; 19: 947-966. Doi:10.1093/jopart/mun025.

[37] Ngotho J, Kerongo F. Determinants of revenue collection in developing countries: Kenya's tax collection perspective. J Mgt Bus Adm [Internet]. 2014; 1(1). Available from www.writersbureau.net/journals/jmba.
[38] Olando CO. An assessment of financial practice as a determinant of growth of savings and credit co-operative societies' wealth in Kenya: The case of Meru County [Unpublished $\mathrm{PhD}$ Thesis]. Nairobi, Kenya: Kenyatta University, 2012

[39] Pandey IM. Financial management. $9^{\text {th }}$ ed. New Delhi: India Vikas publishing House PVL Ltd, 2010.

[40] Mwangi M, Birundu EM. The effect of capital structure on the financial performance of small and medium enterprises in Thika Sub-County, Kenya. Int J Hum Soc Sci. 2015; 5 (1): $151-156$

[41] Kinyua AN. Factors affecting the performance of small and medium enterprises in the jua kali sector in Nakuru Town, Kenya [Unpublished Master's thesis]. Nakuru, Kenya: Egerton University, 2014.

[42] Mwangi LW, Makau MS, Kosimbei G. (2014). Effects of working capital management on performance of non-financial companies listed at the Nairobi Stock Exchange. Euro J of Bus Mgt. 2014; 2014:195-205.

[43] Kweri F.N. Challenges of strategy implementation at Ritho farmers' cooperative society [Unpublished MBA Project]. Nairobi, Kenya: University of Nairobi; 2011.

[44] Makunyi. A survey of methods used by the Kenya tourist board in marketing adventure tourism, in the Mount Kenya region [Unpublished Master Thesis]. Nairobi, Kenya: Kenyatta University, 2011.

[45] Abdul R, Nasr, M. Working capital management and profitability- case of Pakistani firms. Int Rev Bus Res Pap. 2007; 3(1), 279-300.

[46] Olando O, Mbewa M, Jagongo A. The contribution of SACCO financial stewardship to growth of SACCOs in Kenya. Int J Hum Soc Sci. 2013 September 17; 3.

[47] Phillips, R. Stakeholder theory and organisational ethics. San Francisco: Berrett-Koehler, 2003

[48] Makokha SWA, Alala O, Musiega D, Manase GW. Determinants of revenue collection maximization among county governments: A Case of Kakamega County. Int J Mgt Sci Tech. 2014; 2(4)

[49] Baird S, McIntosh C, Ozler B. Cash or condition: Evidence from a randomized cash transfer program. World Bank Working Paper, 2010.

[50] Hicks J, Kremer M, Mbiti I, Miguel E. Vocational education voucher delivery and labor market returns: A Randomized evaluation among Kenyan Youth. Report to World Bank Spanish Impact Evaluation Fund. 2011

[51] Glennerster R, Kremer M, Mbiti I, Takavarasha K. Access and quality in the Kenyan education system: A review of the progress, challenges and potential solutions. Nairobi: Office of the Prime Minister of Kenya, 2011.

[52] Sulaiman M, Zakari MA. Efficiency and effectiveness of Waqf institutions in Malaysia: Toward financial sustainability. Kuala Lumpur, Malaysia International Islamic University Malaysia, 2014.

[53] Siraj SA. An empirical investigation into the accounting, accountability and effectiveness of Waqf management in the State Islamic Religious Councils (SIRCs) In Malaysia 
[Unpublished PhD Thesis]: Cardiff University, 2012.

[54] Chandra H, Rahman AA. (2010). Waqf investment: A case study of Dompet Dhuafa Republika, Indonesia. Shariah J. 2010; 18(1): 163-190.

[55] Doloi H. (2009). Relational partnerships: The importance of communication, trust and confidence and joint risk management in achieving project success [serial online]. Const Mgt Econ. 2009; 27(11), 1099-1109. Doi:10.1080/01446190903286564

[56] Ruto SJ, Ongwenyi JN, Mugo JB. (2009) Educational marginalisation in northern Kenya. Nairobi, Kenya: Education for All Global Monitoring Report 2010, 2009.

[57] Besel K, Charlotte LW, Klak J. Nonprofit sustainability during times of uncertainty. Non-profit Management and Leadership. 2011; 22(1): 53-65.

[58] Flannery MJ, Hankins KW. A theory of capital structure adjustment speed. Working paper, University of Florida, USA; 2007.

[59] Ritter JR, Huang R. Testing theories of capital structure and estimating the speed of adjustment. J Fin Quant Anal, 2008;
$1-14$.

[60] National Council for Nomadic Education in Kenya [NACONEK]. The national council for nomadic education in Kenya (NACONEK) five year strategic plan (2015-2020). Nairobi: Government Printers, 2015.

[61] Ombado, G. Identifying and maximising SACCO's potential. ACCOSA Newsletter. 2010; 2(2): 2-6.

[62] Mugenda OM, Mugenda AG. Research methods: Quantitative and qualitative approaches. Nairobi Kenya: ACTS, 2003.

[63] Nunnaly, J. Psychometric theory. New York: McGraw-Hill. 1978

[64] Republic of Kenya. A Policy framework for re-aligning education to the constitution 2010 and vision 2030 and beyond. Nairobi: Government Printers, 2012.

[65] Uwezo, Are our children learning. Nairobi: Uwezo East Africa at Twaweza, 2012. 